\title{
"You Must Cut That Long and Stinking Thing": Uncovering the Lived Experiences of Uncircumcised Pokot Women in North-Eastern Uganda
}

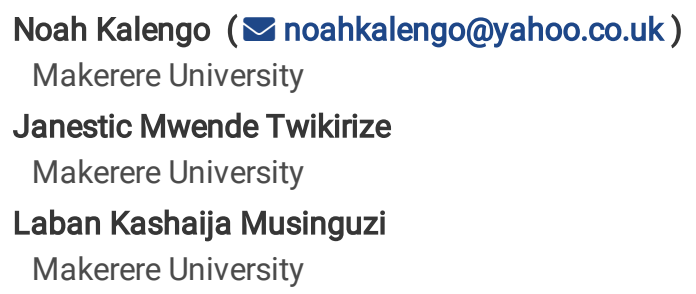

Research Article

Keywords: Intimate partner violence, home desertion, Female circumcision, Sexual enjoyment, Stigmatization of children, Serial interviewing

Posted Date: January 17th, 2022

DOI: https://doi.org/10.21203/rs.3.rs-1158267/v1

License: (c) (1) This work is licensed under a Creative Commons Attribution 4.0 International License. Read Full License 


\section{Abstract \\ Background}

This paper explores the lived experiences of uncircumcised women among the Pokot community in North-Eastern Uganda, where female circumcision remains a dominant practice.

\section{Methods}

This was a qualitative study based on thirty (30) serial interviews with 15 uncircumcised women in the Pokot local language between August and October 2021. Five (5) Key Informant Interviews were also conducted with key informants from Amudat District. A Focus Group Discussion with women was organized as an entry point to identify the initial uncircumcised woman. Uncircumcised women were recruited using respondent driven sampling. Data was analyzed thematically and pseudonyms were used for participants during data analysis. The key themes that emerged during data analysis are; difficulty getting a marriage partner, exclusion from cultural ceremonies, stigmatization of children, not mixing with circumcised in community meetings, less difficulties while giving birth and sexual enjoyment during sexual intercourse.

\section{Results}

Participants expressed greater understanding of female circumcision and the procedure although they were not circumcised. Difficulties in getting marriage partners, bullying by co-wives, rejection by elders and relatives, stigmatization of their children, exclusion from cultural ceremonies and rituals and denial to mix with circumcised women in community meetings were the main experiences mentioned by uncircumcised women. Participants also revealed attempted suicide and murder, home desertions, Intimate partner violence and child abuse as well as early marriages as the main effects associated with their position against female circumcision due to feelings of Ioneliness, rejection, shame, anger and stress. Notwithstanding, sexual enjoyment during sexual intercourse epitomized by ease of reaching orgasms as well as less complications while giving birth were mentioned by participants as their positive experiences.

\section{Conclusion}

Uncircumcised women continue to experience psychosocial challenges in communities where female circumcision is deeply entrenched and perceived as the only passage to womanhood. This call for intensified awareness of the population on the challenges associated with female circumcision while demonstrating the positive experiences mentioned by uncircumcised women.

\section{Background}

There are contestations between human rights activists and African communities practicing female circumcision as regard to the contextual definition of female circumcision $(1,2)$. The African communities accuse human rights activists of using Female Genital Mutilation (FGM) as a way of making the practice look barbaric, dehumanizing and a violation of human rights of girls and women. The World Health Organisation (WHO) (3) defines female circumcision as all actions involving injury to the female genital organs for nonmedical reasons. International and regional legal instruments classify female circumcision as a human rights violation with over 200 million girls and women across the world estimated to have undergone the practice $(4,3,5,6)$.

Female circumcision in countries like Somalia, Mali, Guinea, Djibouti, Sudan, and Egypt is considered an accepted practice (social norm). In most of these countries, the prevalence rates of female circumcision remain at approximately $90 \%(7,8-10)$. Many contextual factors have been raised by the practicing communities in these countries to justify the practice including; proper hygiene or cleanliness among women, marriageability, a rite to passage from childhood to womanhood, low sexual desire among the circumcised, wealth accumulation and women's economic dependency (9-16).

In Uganda, female circumcision is practiced among the Sabiny in Kapchorwa, Bukwo and Kween Districts in Elgon sub-region as well as the Pokot, Tepeth, and Kadam in Nakapiripirit, Moroto and Amudat Districts in Karamoja sub-region $(17,18)$. Although the prevalence of female circumcision among the Sabiny, Tepeth and Kadam has reduced to about $1.4 \%$, the practice is still dominant among the Pokot of Amudat District (17). It is believed that over $54 \%$ of the Pokot girls and women have undergone female circumcision $(17,18)$. However, this has reduced compared to Uganda Demographic and Health Survey (UDHS) (19), which estimated the prevalence rate at 95\% and Uganda 
Women Network at $80 \%$ in 2016 (20). The persistence of female circumcision among the Pokot is associated with strong social values and beliefs and high illiteracy levels among women at $42.4 \%$ compared to the national figure of $32.4 \%$ (17).

The sustained campaigns against female circumcision by state and non-state actors backed by legal instruments has led to increasing number of uncircumcised girls and women among the practicing communities $(5,7,15,16,21-25)$. According to the WHO (2018), annually about 30 million uncircumcised girls and women (15-49 years) in Africa and Asia are at a risk of undergoing the practice due to increasing pressure from their relatives and parents. Besides, uncircumcised girls and women are viewed by the practicing communities as deviant people who have gone against the culturally accepted norm $(18,26-28)$.

The refusal by uncircumcised women to bow to the socio-cultural norms that defines them in the community alienates them from their own communities and thus they cease to have an equal status of belonging as compared to those that are receptive(28). In other words, they lose the entitlements of belonging $(11,29,30,31,32,33,34,35,36)$. Culturally accepted norms like female circumcision are backed by societal norms that must be followed by families to be accepted within their communities $(37,11,12,38,39)$. These social norms place pressure on parents to persuade their daughters to undergo the practice in order to prepare them for marriage and adulthood (15, 40-43).

Notwithstanding the restrictions against female circumcision, pressure on the uncircumcised women to respect and adhere to the social and cultural values and beliefs that defines them is often rife $(44,45,23,45,10,46)$. As a result, uncircumcised women that cannot stand the social pressure from their parents, marital partners, relatives and friends have been forced to secretly undergo female circumcision in their communities $(15,41,42,47,48,20)$. Nonetheless, some of the uncircumcised women have stood their ground against the practice $(5$, $17,18,45,49)$. However, little evidence is available to explain their lived experiences as they continue to live in a community that considers them deviants. It is against this backdrop that, the study sought to explore the lived experiences of uncircumcised Pokot women in NorthEastern Uganda.

\section{Methodology}

\section{Research design}

We adopted a qualitative approach guided by interpretive research paradigm. The adoption of the interpretative approach was informed by the desire to gain a deeper understanding of the lived experiences of uncircumcised Pokot women from their own perspective. The design allowed us to carry out repetitive visits and engross in the community for effective interaction with the participants.

\section{Study site and sampling}

We conducted the study among the Pokot community in North-eastern Uganda, where over $54 \%$ of the women are circumcised compared to the national figures of $1.4 \%(17,18)$. We therefore purposively selected the Pokot community where female circumcision remain highly cherished backed by strong cultural systems $(18,5)$. Female circumcision among the Pokot is backed by strong patriarchal norms making life of those not circumcised vulnerable (5). The Pokot depend on livestock as their main source of livelihood (17). This has also been tagged to female circumcision with circumcised women fetching more cows than those not circumcised (50).

Thirty (30) interviews were conducted with 15 uncircumcised women. The serial interviews were conducted within an interval of one month using the same questions to achieve saturation. Five (05) Key Informant Interviews were conducted with key informants from Amudat District in North-Eastern Uganda. The sample size for uncircumcised women was determined using Creswell's (1998) qualitative sampling framework and they were recruited using Respondent Driven Sampling (RDS) technique (51). A Focus Group Discussion with women irrespective of their circumcision status was organized as an entry point with support of officials from two Non-Governmental Organizations operating in the area (National Association of Women Organization in Uganda and ZOA-Uganda) and Community Development Officers (CDOs) from Amudat District Local Government. The FGD helped us to get initial respondents that were later used to locate other study participants (uncircumcised women). For the selection of District officials to participate in Key Informant Interviews, purposive sampling was applied. The key informants played a big role in reinforcing the responses from uncircumcised women.

\section{Data collection and analysis}

We adopted Serial Interviewing to collect data from uncircumcised women (52). Each Serial Interview took between 40-60 minutes. The Serial Interviews were conducted in Pokot language with support of two native female Research Assistants and at places selected by the participants. The Research Assistants (RAs) fluent in Pokot, Swahili and English were trained for two days. During training, the RAs were retooled on the Interview Guide and Code of Ethics for Research in the Social and Behavioral Sciences involving human participants. Consent of participants to take part in the study as well as having the interviews recorded was also emphasized during training. 
During data collection, participants were asked to share their understanding of female circumcision, knowledge on procedure and seasons when the practice is performed as well as describe their own experiences because of their position against female circumcision. There was a lot of flexibility during interviews to allow participants freely express themselves. The interviews with uncircumcised women were conducted in Pokot and fully recorded. A debriefing meeting was organized with Research Assistants (RAs) everyday to have a reflection on the emerging issues and information.

The study adopted Braun and Clarke Thematic Framework of analysis (53). The first step of analysis involved transcribing and translating the recorded audios and reading through by three different researchers. Verification of the translations was confirmed by a Pokot native from Makerere University eloquent in English. After confirming the translations, we started coding the transcribed data by giving short phrases like meaning of female circumcision, rejection, participation in cultural dance "Naleyo Dance", struggle to get a marriage partner, bullying by co-wives, denial of sex by the husbands and participation in meetings, running away from home, child neglect, denial of basic needs, enjoying sex, early marriages, attempted suicide and murder. The short phrases were used to generate major themes like discrimination and stigmatization, participation in community meetings, intimate partner violence, no difficulties during delivery and enjoying sex. These major themes were reviewed by the three different researchers independently to check for validity and accuracy and report writing started thereafter. Notably, the process of data analysis was highly iterative involving the researchers moving back and forth to ensure accuracy and consistency of the data collected.

\section{Ethical considerations}

The study was approved by Makerere University School of Social Sciences Research and Ethics Committee (MAKSS REC09.21.493) and Uganda National Council for Science and Technology (UNCST SS1046ES). Permission to conduct research was also obtained from Amudat District authorities. Since all the study participants were above 18 years of age, written informed consent was obtained from them. Participants who could not write, a thumbprint was used as approved by the ethics committee. Before participants giving their informed consent, the Investigators explained to them the purpose, selection criteria, likely risks and benefits of the study in their local language (Pokot).

To reduce harm and ensure confidentiality, female Research Assistants were recruited to carry out interviews with uncircumcised women. Participants were also assured not to respond to any questions they didn't feel comfortable with and asked for breaks at any time during the interviews. Given the fact that interviews were conducted during the COVID-19 pandemic, anti-COVID 19 guidelines and Standard Operating Procedures (SOPs) by the government of the Republic of Uganda were highly observed. The participants were given facemasks and sanitizers as well as encouraged to social distance during interviews.

\section{Results}

\section{Description of study participants}

The findings are based on 30 Serial Interviews with fifteen (15) uncircumcised Pokot women as well as five (5) Key Informant Interviews with District officials. Ten (10) of the participants had attained primary education while five (5) secondary education. Nine (9) of the participants were married, four (4) not married while two (2) were still in school. Out of the 15 study participants, ten (10) were aged 18-25, three (3) aged 26-35 and two (2) aged 30 years and above. These are active age blackest for circumcision among the Pokot community. Negative psychosocial experiences were more pronounced among participants in the rural areas than their counterparts in the urban centers.

The experiences that emerged during data analysis are; difficulties in getting marriage partners, bullying by co-wives, rejection by elders and relatives, stigmatization of their children, exclusion from cultural ceremonies and rituals and denial to mix with circumcised women during community meetings. These have resulted into attempted suicide and murder, home desertions, Intimate partner violence and child abuse and drop outs as well as early marriages due to feelings of loneliness, rejection, shame, anger and stress. Two positive experiences also surfaced during data analysis; sexual enjoyment during sexual intercourse epitomized by ease of reaching orgasms and less complication while giving birth.

\section{Knowledge about female circumcision}

Before recounting their experiences, participants were asked to share their understanding of female circumcision and knowledge on the process for someone to undergo the practice. All the participants demonstrated greater understanding of female circumcision and the different seasons when the practice is conducted. The level of understanding of female circumcision across the participants was irrespective of the level of education, age, marital status or religion. Participants described female circumcision as the "cutting of the 
female private parts, especially the clitoris using a sharp knife or razor blade". The participants further mentioned that female circumcision is performed during the months of March, April, August and September of every even year targeting girls between the age of 10-15 years with the intention of preparing them for marriage and transition to womanhood.

All the participants stated that a traditional dance "Naleyo Dance" is performed in the community to alert young girls about to undergo circumcision and relatives to prepare the local brew "kumi-ket" for elders during the circumcision. One of the key informants revealed that, on the day of circumcision, the girls are taken to the river to bath and their fathers smear them with black mud on the face as the cutter "Koko-Melkong" prepares the stones where the girls are circumcised. After circumcision, the girls are baptized "Chemeril" and they are isolated from the community until they heal. After healing, the girls are ushered to the nearby trading center while dancing to get gifts "Meseren" from people.

A group of participants mentioned that, the decision to undergo female circumcision is bestowed in parents and elders in the community. The parents decide when the girl is to undergo circumcision and is responsible for disciplining those that express fear during the circumcision process. However, another group expressed that the role of parents and elders have since dwindled with many young girls undergoing circumcision due to peer influence without informing their parents and elders in the community. One the participants revealed that, the decision not undergo circumcision is not absolute due to persistent stigmatization and discrimination in the community. Rebecca recalled, I one time felt like going for circumcision when I was still young because of the persistent insults from my stepmother telling me that I must cut the long and stinking thing between my legs.

\section{Refusal to give names to their children by husbands and relatives}

Married participants mentioned that their husbands with support of relatives after discovering that they are not circumcised refused to give names to their children claiming that the children are a "bad omen" to the family since they are born out of uncircumcised women. The participants expressed anger over humorous names like "magangandet" literally meaning outcast given to their children to depict them as a curse to the family and community. They demonstrated that giving names among the Pokot is vital in clan and family identification as well as telling the child's birth story.

The participants further stated that, discrimination and stigmatization of their children have been extended in schools forcing some of their children to drop out of school due to bullying and teasing by their peers. These voices were re-echoed by participants still in school who reported verbal abuse from fellow peers whose parents are circumcised. Out of the 15 uncircumcised women interviewed, we recite stories of 3 participants;

"In our culture the husband or father in-law is the one to name after the child because that name is used as a clan or family identity and sometimes help to communicate about the child's birth story but I struggled with my husband to give names to our children because his parents and elders had asked him not to name them saying that they are a curse to the family" (Nancy)

"My son was forced to drop out of school because of the persistent teasing and bullying from peers that he is a son of a woman who is not clean. I reported several times to the school administration for help but I was not helped until my son dropped out of school. What annoyed me so much is that even my husband did not help our child to be resettled in another school." (Bella)

"My children are not allowed to socialize or interact with other children in the community, especially neighbors because they are considered outcasts and unclean. They are always called all sorts of names and mocked by their peers because of my position against FGM. The situation is worse for children from uneducated families." (Margret)

\section{Denial to mix with circumcised women during community meetings}

Some participants narrated how they have been denied mixing with circumcised women on several occasions during community meetings claiming that they smell badly. Besides, not mixing with circumcised women, they were also not allowed to contribute any ideas during community meetings. These experiences were augmented by key informants who revealed that uncircumcised women are denied positions in leadership because most of the decisions on who to contest among the Pokot are decided by elders. As a result, some of the participants expressed feelings of rejection and unfit to stand in public places thus alienating themselves from participation in community meetings and decision making process.

"I remember one time I went for a community meeting to discuss about cattle raids in the area but the elders said those circumcised should not mix with those not circumcised. I was not even allowed to say something in that meeting. I felt so bad because our animals had also been raided by warriors and I wanted to share my challenges with elders". (Rebecca)

Page 5/13 
"Uncircumcised women cannot talk in the meeting and are always called young girls "Chepto". This has forced many young girls to succumb to pressure and get circumcised. My mother is a muganda but she was compelled to be circumcised because of what she was going through". (Community Development Officer)

\section{Denial of sex and basic needs at home}

Married participants revealed denial of sex and other basic needs at home as one of the strategies used by their husbands to pressurize them to undergo female circumcision after realizing that they are not circumcised. The pressure to circumcise has been exacerbated by their co-wives who influence their husbands not to have sex with them claiming that dirty things come out of their private parts, smell badly and engage in extra marital affairs. Some of the participants revealed having deserted their matrimonial homes due to pressure from their co-wives while others reported constantly engaging in physical fighting with their husbands and co-wives over allegations of extra marital affairs. Three stories from the participants interviewed;

"I remember one time my husband got a full cabbage, boiled it and placed it on the table. When I asked him how he was going to eat the full cabbage that is not cut, he told me that I am like that cabbage. That I first go for cutting and come back when I am like ready cabbage. I felt so bad and decided to leave him and started staying with my mother. I don't feel like reconciling with that man because he really mistreated me". (Juliana)

"My husband got another woman after telling him that I am not circumcised. One time that woman confronted me in front of my children saying that she is the only woman in the family who doesn't smell. My friend, I grabbed her and by the time people came to separate us, I had already given her enough ahahaha" (Bella)

"My father used to fight with mum because she refused me to undergo circumcision. One day mum told me to leave home and go to Kalas Girls Primary School to get formal education. I remember spending a night walking to that school because it's very far from our home in Loroo Sub county." (Linda)

\section{Refusal by elders/clan leaders to bless their marriage}

Participants revealed that marriage blessings in their culture are given by elders in the community. However, these blessings have been tied to female circumcision. Those who defied female circumcision are always blamed for their marriage misfortunate and elders do not visit their homes. In the case of Rachael "I am always harassed and abused by my In-laws whenever I try to go and pick food from the granary claiming that I will cause food insecurity to the family since I am not circumcised. I have tried several times to tell my husband to secure a plot far from his parents so that we can leave this place but he is always influenced by his parents. The harassment and stress is too much".

The participants also stated that the economic benefits tagged on circumcised women during marriage have made elders not to bless their marriages. They revealed that uncircumcised women fetch less in terms of dowry as compared to those circumcised. This perception was more pronounced among the uneducated parents and those in the rural areas, where the cultural values are deeply entrenched.

"I am not circumcised because I am from a strong Christian family, but what pains me so much is that the parents to my husband refused him from paying dowry to my parents because I am not circumcised. They even vowed never to come and visit us at my home. I always feel bad because my children tell me that they are stigmatized when they go to visit their grandparents" (Bella)

"I remember one time my father in-law telling me in front of my children that look at this girl with seven horns; you know the shaper end of the clitoris looks like a horn. I felt so embarrassed, degraded and decided to leave that home up to now I have gone back." (Lina)

\section{Exclusion from cultural ceremonies and functions}

Cultural ceremonies and functions have since time immemorial been used to build social bond, unity and communicate different gender roles among the Pokot community. However, participants mentioned that unlike circumcised women, those not circumcised are not allowed to participate in cultural ceremonies like "Nareyo" a traditional dance performed for those about to undergo circumcision or get married. They are also not allowed to serve elders during traditional ceremonies because of the myth that they smell badly and still young girls. A group of participants revealed having stopped attending traditional ceremonies due to discrimination and stigmatization by elders. Out of the fifteen uncircumcised women interviewed, we cite stories of two participants;

"My cousin sister was getting married and she asked me to serve elders from the husband's side but one of my uncles who knew that I am circumcised stopped me from serving them claiming that I was not clean to serve elders and I will bring bad blessings to their daughter's 
marriage. I felt so bad and decided to stop attending traditional and family functions." (Nancy)

"One day I sent my child to the neighborhood to collect cow dung for beautifying our house but the man chased him and called him all sort of names because I am not circumcised. He shouted at him saying he should not collect cow dung from their kraal because he will bring curse on their family. They have also stopped my children from socializing with their children." (Margret)

Besides, discrimination at traditional functions uncircumcised women continue to be denied access to some public places like water collection points and kraal to collect cow dung to beautify their houses claiming that they leak from their private parts. This stigmatization is also extended to their children, who are always harassed by fellow children at the water points and in extreme cases not allowed to fetch water. A story by one of the participants interviewed; "Sometimes when we go to the water collection points, those circumcised women tell us to first wait for them to fill their jerricans before we make the water dirty claiming that we leak from our private parts." (Isah)

\section{Difficulties in getting a marriage partner}

Both married and unmarried participants mentioned difficulties in getting a marriage partner as one of the challenges faced. This according to participants is attributed to the myth that uncircumcised women are a curse to the family. This was exacerbated by hilarious names given to uncircumcised women like "Chemalayinan" and "Chineyomegtilinye" literally meaning a prostitute and dirty woman respectively. As a result, men shun away from falling in love with uncircumcised women for fear of insults and bullying from the community. Some of the participants revealed having abandoned their original communities to other areas where their circumcision status is not known to get marriage partners.

"Boys in the village used to tell me that I will not get someone to me marry me because I am not circumcised. I was forced to leave the village and come to Amudat Town Council where nobody knows that I am not circumcised and got a boyfriend although we have not yet started staying together". (Cheleo)

\section{Enjoying sex during sexual intercourse}

Most participants mentioned enjoying playing sex with their husbands and boyfriends saying that they experience sweet sensitivity since they are intact. Although circumcised women were not targeted to get their experience on sexual feelings, participants revealed having received several complaints from their friends who are circumcised that they feel a lot of pain while playing sex. Margret recited her psychosexual experience "I have my friend who is circumcised but she tells me that she lost interest in playing sex with her husband because she feels a lot of pain whenever they have sex and sometimes bleeds. Personally, I have never felt pain apart from the very first time I had sex because I was still a virgin."

Bella recalling her sexual experience; I feel happy whenever I have sex with my husband because I enjoy a lot unlike circumcised women whom their husbands say feel a lot of pain because their penetration area is very small.

\section{Less complications while giving birth}

The participants with children pointed out less complication while giving birth as one of the experiences they enjoy for not being circumcised. In the case of Bella, I have five children now and I have never got any problem while giving birth yet my friends who are circumcised have delivered from Moroto Hospital and some have undergone caesarean section after failing in our health facility here. These experiences have taught me a lesson and I pledged not to circumcise my daughters although my relatives sometimes try to influence me to circumcise my daughter.

\section{Discussions}

The paper examines the lived experiences of uncircumcised Pokot women in North-Eastern Uganda. Whilst the prevalence of female circumcision at national level is $1.4 \%$, the practice remains high among the Pokot community at $54 \%(17,18,53)$. The findings provide evidence that uncircumcised women face several psychosocial challenges as they continue to live in the community that stigmatizes and discriminates against them because of their position against the practice. These experiences have resulted into attempted suicide and murder, home desertions, Intimate partner violence and child abuse as well as early marriages due to feelings of loneliness, rejection, anger, depression and stress.

The participants revealed suffering from multiple marital challenges; including failure to name their children by their husbands and relatives, denial of sex and basic needs at home and refusal to bless their marriage. The situation is exacerbated by actions of circumcised co-wives who always tell their husbands not to have sexual intercourse with uncircumcised co-wives claiming that they are unclean and 
smell badly. The myth that uncircumcised women have high sexual libidos, unclean and likely to engage in premarital affairs has also contributed to intimate partner violence and child abuse. Nevertheless, these sexual myths have been disapproved $(29,55,56)$. The sexualisation of the woman's body and polygamous marriage system among the FGM communities have also worsened matrimonial challenges among the uncircumcised women $(8,28,29,33,57-60)$. The participants stated that the limited psychosocial support directed towards uncircumcised women have made some of them to develop suicidal and murder thoughts or desert their conjugal homes. An interaction with key informants revealed that several uncircumcised married women have divorced due to persistent harassment by their husbands and relatives. These findings are in conformity with several scholars who discovered that matrimonial challenges faced by uncircumcised women in FGM communities are not bearable(11, 21, 30, 30, 35, 61-63).

The act of denying uncircumcised women from mixing with circumcised women during community meetings and taking up leadership positions was identified by participants as one of the key experiences. Besides denial to participate in decision making process, uncircumcised women have been denied access to ownership of property as noted by several scholars $(29,33,64,65)$. Whilst the Constitution of the Republic of Uganda, the Prohibition of FGM Act, Succession Act, Equal Opportunities Commission Act, and Domestic Violence Act are very pronounced on the rights of women in Uganda, cultural myths continue to dominate the Pokot community where uncircumcised women are constantly denied from taking up leadership positions on claims that they are still girls "chepto"thus not allowed to participate in decision making. As noted by Awich (50), the denial of uncircumcised women from filling leadership positions has been worsened by the patriarchal system of social organization. The system advances women dependence on men and elders in the community as opposed to self-sufficiency. Uncircumcised women expressed that the myth within the community that someone remains a girl until she goes through female circumcision continue to be exploited by elders and men to extend their preeminence and control over resources $(49,58,66)$. Notwithstanding, some uncircumcised women, especially in urban centers and those educated have challenged the odds by contesting in high political offices. Therefore education as noted by several scholars remains a key factor in influencing power relations and control over resources among the FGM communities $(7,9,34,66)$.

Whilst someone would expect uncircumcised women to be the direct victims of the broken up social relationships, discrimination and stigmatization is also extended to their children in the community and in schools. Consequently, some of the children of uncircumcised women are forced to drop out of school because of the persistent teasing and bullying from their peers at school and within the community. Similar reactions characterized by ostracism and stigmatization towards children of uncircumcised women were re-echoed by key informants at the district level. Some of the participants revealed that efforts to get redress from school administrators regarding their children at school have proved futile. These barbaric behaviours against uncircumcised women and their children have been reaffirmed by several authors on the effects of deviant behaviours in the community $(46,61,62)$.

Most of the participants stressed difficulty in getting marriage partners as one of the horrible experiences faced. The participants revealed this was attributed to hilarious names like "Chineyomegtilinye" literally meaning dirty woman given to them in the community thus scaring away potential intimate partners. As a result, some of participants that could not stand the humiliation deserted their communities and relocated to areas where their circumcision status was not known to get intimate partners. However, even after getting marriage partners, their husbands and relatives started mistreating them and their children after discovering that they are not circumcised. Difficulty to get a marriage partner was exacerbated with bride price attached to circumcised women $(11,66)$. Participants expressed fear that efforts by Civil Society Organization to engage elders over tagging bride price to female circumcision have not yielded much due to limited support from the political elites.

The broken up social relationships have also impacted on uncircumcised women as they are denied from benefiting in government development programmes such as Uganda Women Entrepreneurship Programme (UWEP), Youth Livelihood Programme (YLP), and community savings, where their local leaders are actively involved in selecting the beneficiaries. This has been compounded by government failure to appreciate the situation of uncircumcised women and design programmes targeting both circumcised and uncircumcised women at identification and selection level. Circumcised women among the Pokot are highly respected in the community because they fetch a lot of wealth during traditional ceremonies like marriage ceremonies. As noted by key informants, circumcised women fetch more animals (cows) as compared to their counterparts. However, the situation is different for educated and uncircumcised women in urban centers, where majority benefit from the government programmes irrespective of the circumcision status stigmatization notwithstanding. Several authors concur that education and urbanization are key elements in the fight against negative effects associated with FGM and improving women empowerment $(67,45)$.

Although the promoters of female circumcision have subjected uncircumcised women to unbearable experiences as earlier noted, participants revealed a number of good experiences including, sexual enjoyment exemplified by reaching orgasms and minimal complication while giving birth. 
Evidence has been documented on the relationship between female circumcision and birth complications. Several medical experts concur that, uncircumcised women are likely to suffer less complications while giving birth as compared to their counterparts (68, $61,58,25,55$, $55,69)$. This was reaffirmed by the study participants who reported receiving less complication while giving birth as compared to their counterparts who are circumcised. The participants further mentioned that female circumcision exposes those undergoing the ritual to STDs since the same cutting tool is used on all the girls. Some of the participants reported that the chances of uncircumcised women getting HIV/AIDS during sexual intercourse are minimal. These myths without any scientific evidence are not only likely to escalate the spread of STDs but also undermine the campaigns of family planning. This confirms findings by several scholars that uncircumcised women are less likely to use contraceptives as compared to circumcised women (70).

The study also revealed improved sexual functioning (high sexual pleasure) as one of the key positive experiences reported by uncircumcised women. Even though little evidence is available to support their argument, medical professionals confirmed that tampering with the woman's clitoris and labia minora may result into development of inelastic scars and adhesions around the excised areas thus causing impaired sexual functioning (21). Several authors while investigating lived experiences of circumcised women in Nigeria picked some voices of feeling pain during sex by circumcised women (56). Therefore, until uncircumcised women are given a platform and assurance that opening up about their status will not lead to stigmatization, efforts to curb the vice will continue to move in silos.

Several scholars concur that female circumcision is a deeply entrenched cultural practice among the Pokot community in eastern Uganda that is looked at as the only passage to adulthood $(18,48,50)$. Legal instruments have been developed against the practice; however cases of female circumcision continue to be reported due to strong social values and psychosocial distress experienced by those not circumcised $(2,2,71)$. Therefore, documenting the positive experiences associated with not being circumcised can be a blessing in the fight against FGM.

\section{Conclusions}

Uncircumcised women have been exposed to several experiences making their living in the community difficult. These experiences have resulted into attempted suicide and murder, home desertion, Intimate Partner Violence and child abuse as well as early marriages due to feelings of loneliness, rejection, anger, shame, anxiety and stress. Therefore, developing integrated psychosocial support programmes involving all stakeholders and documentation of scientifically proven benefits of not being circumcised can help in the fight against female circumcision. Further studies need to be conducted on the scientific benefits of not being circumcised and protective factors adapted by uncircumcised women and girls to navigate in a community that consider them deviant.

\section{Abbreviations}

CDO

Community Development Officer

FM

Female Circumcision

FGM

Female Genital Mutilation

RDS

Respondent Driven Sampling

UDHS

Uganda Demographic and Health Survey

UWEP

Uganda Women Entrepreneurship Programme, MAKSSREC:Makerere University School of Social Sciences Research and Ethics Committee, UNCST:Uganda National Council for Science and Technology.

\section{Declarations}

\section{Ethics approval and consent to participate}

The study was approved by Makerere University School of Social Sciences Research and Ethics Committee (MAKSS REC09.21.493) and Uganda National Council for Science and Technology (UNCST SS1046ES). All the study methods and procedures were performed in accordance with the Principles of the Declaration of Helsinki. The study participants were thoroughly informed of the study objectives and 
written informed consent was obtained from them. Participants who could not write, a thumbprint was used as approved by the Ethics Committee (MAKSS REC \& UNCST).

\section{Consent for publication}

Not applicable

\section{Competing interests}

The authors declare that they have no competing interests

\section{Author details}

$\mathrm{KN}$ is an Assistant Lecturer at the Department of Sociology and Social Administration, Faculty of Arts and Social Sciences, Kyambogo University, Kampala, Uganda. KN a PhD student at the Department of Social Work and Social Administration, Makerere University.

JMT is a Senior Lecturer at the Department of Social Work and Social Administration, School of Social Sciences, College of Humanities and Social Sciences, Makerere University Kampala.

LKM is a Lecturer at the Department of Social Work and Social Administration, School of Social Sciences, College of Humanities and Social Sciences, Makerere University Kampala.

\section{Acknowledgements}

Authors confirm that they have complete access to all the materials in the study and responsible for the decision to submit the manuscript for publication. The authors also extend appreciation to study participants.

\section{Authors' contributions}

KN conceived the study as part of his PhD and participated in the study design, data analysis and drafting of manuscript; JMT participated in study design, data analysis and review of manuscript; participated in review of manuscript for important intellectual content; LKM participated in study design and review of manuscript for important intellectual content. All authors read and approved the final manuscript and consented to its submission for publication.

\section{Funding}

Not applicable

\section{Availability of data and materials}

The datasets/transcripts used and analyzed for the study are available from the corresponding author on reasonable request.

\section{References}

1. Tamale S. The right to culture and the culture of rights: A critical perspective on women's sexual rights in Africa. Old Wineskins, New Wine Readings Sex sub-Saharan Africa. 2010;53-70.

2. Berer M. The history and role of the criminal law in anti-FGM campaigns: Is the criminal law what is needed, at least in countries like Great Britain? Reprod Health Matters [Internet]. 2015;23(46):145-57. Available from: http://dx.doi.org/10.1016/j.rhm.2015.10.001

3. WHO. management of health complications from female genital mutilation WHO guidelines on the. 2018;(May).

4. Compendium of International and National Legal Frameworks on Female Genital Mutilation, Fourth Edition. Compend Int Natl Leg Fram Female Genit Mutilation, Fourth Ed. 2020;(February).

5. 28toomany. Uganda: The Law and FGM. 2018;(May):1-12.

6. Issell D. The law and FGM: An overview of 28 African countries. 2018;(September):78. Available from: www.28toomany.org/Law

7. Alinia C, Piroozi B, Jahanbin F, Safari H, Mohamadi-bolbanabad A, Kazemi-karyani A, et al. Estimating utility value for female genital mutilation. 2020;1-7.

8. Koski A, Heymann J. Thirty-year trends in the prevalence and severity of female genital mutilation: A comparison of 22 countries. BMJ Glob Heal. 2017;2(4). 
9. Sakeah E, Debpuur C, Oduro AR, Welaga P, Aborigo R, Sakeah JK, et al. Prevalence and factors associated with female genital mutilation among women of reproductive age in the Bawku municipality and Pusiga District of northern Ghana 11 Medical and Health Sciences 1117 Public Health and Health Services. BMC Womens Health. 2018 Sep 18;18(1).

10. Ikonne O, Chukwuma EP. the Prevalence of Female Genital Mutilation/Cutting (Fgm/C) and Men'S Role in Its Practice in Southeast Nigeria. Niger J Med Sociol. 2020;2(1):52-78.

11. Ahmed HM, Shabu SA, Shabila NP. A qualitative assessment of women's perspectives and experience of female genital mutilation in Iraqi Kurdistan Region. BMC Womens Health. 2019;19(1):1-12.

12. Doucet $\mathrm{MH}$, Pallitto $\mathrm{C}$, Groleau D. Understanding the motivations of health-care providers in performing female genital mutilation: an integrative review of the literature. Reprod Health. 2017;14(1):46.

13. Seketian St. Factors influencing the practice of Female Genital Mutilation among women: A case of Kajiado West Constituency, Kajiado County, Kenya.

14. Namulondo J. Female Genital Mutilation: A Case of the Sabiny in Kapchowra District, Uganda: A dissertation submitted in partial fulfilment for the degree: Master in Human Rights Practice. 2009;

15. Andarge MY. The Difficulties of Ending Female Genital Mutilation (FGM): Case of Afar Pastoralist Communities in Ethiopia. Int Inst Soc Stud [Internet]. 2014;1-62. Available from:

https://www.ohchr.org/Documents/Issues/Women/WRGS/FGM/NGOs/ActionForlntegratedSustainableDevelopmentAssociation.pdf

16. Shell-Duncan AMB. Tracing Change in Female Genital Mutilation/Cutting through Social Networks: An Intersectional Analysis of the Influence of Gender, Generation, Status, and Structural Inequality. 2020;(February):1-77.

17. UBOS. UBOS,2018. Uganda National Household Survey 2016/17. Kampala, Uganda;UBOS. 2018 [Internet]. 2018;3. Available from: http://www.ubos.org/onlinefiles/uploads/ubos/UNHS16-17/2016 UNHS FINAL REPORT.pdf

18. UNICEF. Female Genital Mutilation/ Cutting the Republic of Uganda Survey Report. 2017;52. Available from: https://www.unicef.org/uganda/FGM_SurveyReport_October2017_Final.pdf

19. Survey H. Uganda. 2011;

20. Social THE, That N, Women ION. Research on the Social Norms That Perpetrate Female Genital Mutilation ( Fgm / C ) and Its Implications on Women and Girls in Uganda: a Case Study of Amudat District. 2017;(April).

21. Buggio L, Facchin F, Chiappa L, Barbara G, Brambilla M, Vercellini P. Psychosexual Consequences of Female Genital Mutilation and the Impact of Reconstructive Surgery: A Narrative Review. Heal Equity. 2019;3(1):36-46.

22. Earp BD, Johnsdotter S. Current critiques of the WHO policy on female genital mutilation. IJIR Your Sex Med J [Internet]. 2020; Available from: http://dx.doi.org/10.1038/s41443-020-0302-0

23. Ameyaw EK, Tetteh JK, Armah-ansah EK, Aduo-adjei K. Female genital mutilation / cutting in Sierra Leone: are educated women intending to circumcise their daughters? 2020;0:1-11.

24. Abathun AD, Sundby J, Gele AA. Attitude toward female genital mutilation among Somali and Harari people, Eastern Ethiopia. Int $J$ Womens Health. 2016;8:557-69.

25. Dotimi DA. Lived Experiences of Women from the Odi community in Nigeria of Female Genital Mutilation. ProQuest Diss Theses [Internet]. 2016;116. Available from: http://libproxy.library.wmich.edu/login?url=https://search.proquest.com/docview/1789297910? accountid=15099\%0Ahttp://primo-pmtna01.hosted.exlibrisgroup.com/openurl/01WMU/01WMU_SERVICES??url_ver=Z39.882004\&rft_val_fmt=info:ofi/fmt:kev:mtx:dissertation\&genr

26. UNICEF, UNFPA. Dynamics of a social norm: female genital mutilation/cutting handouts manual on social norms and change. New York: UNICEF/UNFPA; 2009.

27. UNICEF. Female Genital Mutilation/Cutting: A global concern. 2016; Available from: http://unfpa.org.co/

28. UNICEF. Case study on ending female genital mutilation in the State of Eritrea. 2021;1-12.

29. Eldin AG, Babiker S, Sabahelzain M, Eltayeb M. FGM/C Decision-Making Process and the Role of Gender Power Relations in Sudan. 2018;(October).

30. Glover J, Liebling H, Barrett H, Goodman S. The psychological and social impact of female genital mutilation: A holistic conceptual framework. J Int Stud. 2017 Jun 10;10(2):219-38.

31. Glover J, Liebling H. Reflections on research with survivors of female genital mutilation. Psychol Women Sect Rev. 2017;19(1):17-26.

32. Mapathon G, Hundred E, Ramps G, Efforts UP, Resilience FOF. Successes in 2018 Female Genital. 2019;1(January):1-7.

33. McCauley M, Van Den Broek N. Challenges in the eradication of female genital mutilation/cutting. Int Health. 2019;11(1):1-4.

Page 11/13 
34. Mohammed ES, Seedhom AE, Mahfouz EM. Female genital mutilation: Current awareness, believes and future intention in rural Egypt. Reprod Health. 2018;15(1):1-10.

35. Obaid ZM, Amer AW-A, El Mahdy MAF, Mohammed AEB. Evaluation of Psychological and Sexual Effects of Female Genital Mutilation (Circumcision). Egypt J Hosp Med [Internet]. 2019;74(4):726-34. Available from: https://ezproxy.southern.edu/login? qurl=http\%3A\%2F\%2Fsearch.ebscohost.com\%2Flogin.aspx\%3Fdirect\%3Dtrue\%26db\%3Da9h\%26AN\%3D134257276\%26site\%3Dehostlive\%26scope\%3Dsite

36. Sakeah E, Debpuur C, Oduro AR, Welaga P, Aborigo R, Sakeah JK, et al. Prevalence and factors associated with female genital mutilation among women of reproductive age in the Bawku municipality and Pusiga District of northern Ghana 11 Medical and Health Sciences 1117 Public Health and Health Services. BMC Womens Health. 2018;18(1):1-10.

37. Mackie G. Ending Footbinding and Infibulation: A Convention Account Author ( s ): Gerry Mackie Source: American Sociological Review , Vol . 61, No . 6 ( Dec ., 1996 ), pp . 999-1017 Published by: American Sociological Association Stable URL: https://www.jstor. 2018;61(6):999-1017.

38. Koukoui S, Hassan G, Guzder J. The mothering experience of women with FGM/C raising 'uncut' daughters, in Ivory Coast and in Canada. Reprod Health. 2017;14(1):1-11.

39. Kimani S, Kabiru CW, Muteshi J, Guyo J. Exploring barriers to seeking health care among Kenyan Somali women with female genital mutilation: A qualitative study. BMC Int Health Hum Rights. 2020;20(1):1-12.

40. Understanding Medicalisation of Fgm / C: a Qualitative Study of Parents and Health. 2018;(January).

41. Van Stuijvenberg M, Suur MH, De Vos S, Tjiang GCH, Steyerberg EW, Derksen-Lubsen G, et al. Informed consent, parental awareness, and reasons for participating in a randomised controlled study. Arch Dis Child. 1998;79(2):120-5.

42. Adetunji SG. The impact of parental education level, wealth status, and location on female genital mutilation prevalence in Northwestern Liberia. Diss Abstr Int Sect B Sci Eng [Internet]. 2018;79(7-B(E)):No-Specified. Available from: http://ovidsp.ovid.com/ovidweb.cgi?T=JS\&PAGE=reference\&D=psyc16\&NEWS=N\&AN=2018-21183-037

43. Zurynski Y, Phu A, Sureshkumar P, Cherian S, Deverell M, Elliott EJ. Female genital mutilation in children presenting to Australian paediatricians. Arch Dis Child. 2017;102(6):509-15.

44. Abdulcadir J, Catania L. Conceptualizing Sexual Pain in Women with Female Genital Mutilation / Cutting. Arch Sex Behav [Internet]. 2020;(0123456789):1-4. Available from: https://doi.org/10.1007/s10508-020-01691-1

45. Ahinkorah BO, Elvis J, Jr H, Ameyaw EK, Seidu AA, Budu E, et al. Socio - economic and demographic determinants of female genital mutilation in sub - Saharan Africa: analysis of data from demographic and health surveys. Reprod Health [Internet]. 2020;1-14. Available from: https://doi.org/10.1186/s12978-020-01015-5

46. Kawous R, Allwood E, Norbart E, Van Den METC, Muijsenbergh. Female genital mutilation and women' s healthcare experiences with general practitioners in the Netherlands: A qualitative study. PLoS One [Internet]. 2020;15(7 July):1-13. Available from: http://dx.doi.org/10.1371/journal.pone.0235867

47. Ouedraogo S, Koissy-Kpein SA. An economic analysis of females' Genital Mutilation: How the marriage market affect the household decision of excision. Congrès Annu la Société Can Sci Économiques,. 2012;27.

48. Haaland I. Child marriage, well-being and health seeking behavior. A study among married adolescent girls in the Pokot tribe. 2017; (February):117. Available from: https://www.duo.uio.no/handle/10852/57140

49. Hrvatin I, Šćepanović D. Female Genital Mutilation - Recent Literature Review. Challenges Futur [Internet]. 2018;3(2):90-102. Available from: http://www.fos-unm.si/media/pdf/IP/32_Hrvatin_FGM_recent_literature_review.pdf

50. Awich E, Musinguzi L. Child Abuse and Neglect in Uganda (2017).

51. Heckathorn DD. Respondent-driven sampling: A new approach to the study of hidden populations. Soc Probl. 1997;44(2):174-99.

52. Murray SA, Kendall M, Carduff E, Worth A, Harris FM, Lloyd A, et al. Use of serial qualitative interviews to understand patients' evolving experiences and needs. BMJ. 2009;339(7727):958-60.

53. Braun V, Clarke V. One size fits all? What counts as quality practice in (reflexive) thematic analysis? Qual Res Psychol [Internet]. 2020;00(00):1-25. Available from: https://doi.org/10.1080/14780887.2020.1769238

54. Odukogbe ATA, Afolabi BB, Bello 00, Adeyanju AS. Female genital mutilation/cutting in Africa. Transl Androl Urol. 2017;6(2):138-48.

55. States K. Sudan working paper FGM/C Abandonment Khartoum and Kassala States. 2020.

56. Philips SK. Heroes or victims: The lived experiences of women on female genital mutilation/cutting in northwestern Nigeria. Walden Diss Dr Stud Collect [Internet]. 2016;78(4-B(E)):No Pagination Specified. Available from: http://ovidsp.ovid.com/ovidweb.cgi? $\mathrm{T}=\mathrm{JS} \& C S C=Y \& N E W S=N \& P A G E=$ fulltext\&D=psyc13\&AN=2017-05720-003\%0Ahttp://sfx.library.cdc.gov/cdc?

Page $12 / 13$ 
sid=OVID:psycdb\&id=pmid:\&id=\&issn=0419-4217\&isbn=978-1369361735\&volume=78\&issue=4-

B\%28E 29 \&spage=No\&pages=No+Pagination+Specifie

57. 28 Too Many. FGM in Uganda. 2013;(July):1-76. Available from: https://www.28toomany.org/static/media/uploads/Country

Research and Resources/Uganda/uganda_country_profile_v1_(july_2013).pdf\%0Ahttps://www.cehurd.org/wp-

content/uploads/2015/11/FGM-response-and-R2H-1.pdf

58. Eldin AG, Babiker S, Sabahelzain M, Eltayeb M. FGM/C Decision-Making Process and the Role of Gender Power Relations in Sudan. 2018;(October). Available from: https://knowledgecommons.popcouncil.org/cgi/viewcontent.cgi? article=1549\&context=departments_sbsr-rh

59. Leye E, Eekert N Van, Shamu S, Esho T, Barrett H. Debating medicalization of Female Genital Mutilation / Cutting ( FGM / C ): learning from ( policy ) experiences across countries. 2019;1-10.

60. ICRW. Leveraging Education To End Female Genital Mutilation/Cutting Worldwide. African Heal Sci Spec Issue. 2016;1-19.

61. Mulongo P, Hollins Martin C, McAndrew S. The psychological impact of Female Genital Mutilation/Cutting (FGM/C) on girls/women's mental health: a narrative literature review. J Reprod Infant Psychol [Internet]. 2014;32(5):469-85. Available from: http://dx.doi.org/10.1080/02646838.2014.949641

62. Kalokoh N. The Effects of Female Genital Mutilation on Women of Sierra Leone. ProQuest Diss Theses [Internet]. 2017;166. Available from: https://search.proquest.com/docview/1937532635?accountid=14620

63. Hussen M. Services for women with female genital mutilation in Christchurch: perspectives of women and their health providers. 2014;

64. Graamans E, Ofware P, Nguura P, Smet E, ten Have W. Understanding different positions on female genital cutting among Maasai and Samburu communities in Kenya: a cultural psychological perspective. Cult Heal Sex [Internet]. 2019;21(1):79-94. Available from: https://doi.org/10.1080/13691058.2018.1449890

65. Klein E, Helzner E, Shayowitz M, Kohlhoff S, Smith-Norowitz TA. Female Genital Mutilation: Health Consequences and Complications A Short Literature Review. Obstet Gynecol Int. 2018;2018.

66. Kimathi Nkanatha J, Karuri MN. Female Genital Mutilation: Its Physical-Social Effects on Individuals and Reasons for Its Persistence among Communities [Internet]. Vol. 4. 2014. Available from: www.iiste.org

67. Pashaei T, Ponnet K, Moeeni M, Khazaee-Pool M, Majlessi F. Daughters at risk of female genital mutilation: Examining the determinants of mothers' intentions to allow their daughters to undergo female genital mutilation. PLoS One. 2016;11(3):1-12.

68. Fahmy A, El-Mouelhy MT, Ragab AR. Female genital mutilation/cutting and issues of sexuality in Egypt. Reprod Health Matters. 2010;18(36):181-90.

69. WHO. WHO guidelines on the management of health complicatons from female genital mutilation. WHO Guidel Manag Heal Complicat from Female Genit Mutilation [Internet]. 2016;47. Available from:

http://apps.who.int/iris/bitstream/10665/206437/1/9789241549646_eng.pdf?

ua=1\%0Ahttp://www.ncbi.nlm.nih.gov/pubmed/27359024\%0Ahttp://www.who.int/reproductivehealth/topics/fgm/managementhealth-complications-fgm/en/

70. Masho SW, Orekoya O, Lowery E, Wallenborn JT. Female genital mutilation and contraceptive use: findings from the 2014 Egypt demographic health survey. Int J Public Health [Internet]. 2020;65(7):1151-8. Available from: https://doi.org/10.1007/s00038-02001452-w

71. Charlotte M, Proudman R. The Impact of Criminalisation on Female Genital Mutilation in England From the Perspective of Women and Stakeholders. 2017; 